\title{
Time to Ban Direct-to-Consumer Prescription Drug Marketing
}

\author{
Kurt C. Stange, $M D, P b D$, Editor \\ Ann Fam Med 2007;5:101-104. DOI: 10.1370/afm.693.
}

I $\mathrm{t}$ is time to ban direct-to-consumer (DTC) advertising of prescription drugs. The current US system of pharmaceutical company self-monitoring and Food and Drug Administration oversight is not working. Moreover, it cannot realistically be expected to work. A ban is needed to protect the public's health and the quality of health care.

The research study by Frosch and colleagues in the last issue of Annals ${ }^{1}$ opened a larger discussion and ties to other evidence that point to this conclusion. ${ }^{2,3}$ Their research discovered that in actual practice, DTC ads provide biased educational material and emotional appeals that promote drugs over healthy alternatives. ${ }^{1}$ The online discussion synthesized in the Annals On TRACK feature reveals a complex effect of DTC ads on perceptions, medication prescribing, and adherence. ${ }^{2}$

Other research has raised concerns about the biases $^{4-6}$ and public health effects ${ }^{7-9}$ of DTC advertising. A recent systematic review of the limited evidence found that DTC advertising is associated with patients' request for specific drugs and increased prescription of advertised drugs without benefits in health outcomes. ${ }^{10}$ DTC ads have the potential to increase the appropriateness of prescribing among those who have a condition for which medication is underprescribed, ${ }_{1}^{11,12}$ but the (potentially adverse) effect on the many who see the message but who do not have the condition is inherently harder to measure. . $^{73}$

Together, these sources show an emerging public health tragedy that is happening so surreptitiously that we are blind to the magnitude of the encroaching effect on the quality of health care and the health of Americans.

The use of broad media coverage to encourage prescription drug use is a shotgun where an individualized, personalized approach is needed. These ads present biased appeals to the masses to influence decisions about drugs that are designed (and legally required) to be prescribed within the context of a relationship between a knowledgeable professional and a person who is known as an individual. The broad scope of these ads dramatically increases the potential for adverse outcomes as many viewers may be influenced inappropriately in an attempt to reach a few who could benefit from the message.

The process ${ }^{4,13}$ and consequences ${ }^{10,13-15}$ of DTC ads are complex, influenced by a multifaceted interaction between the prevalence and severity of the condition to be treated, the effectiveness of the treatment, the severity and frequency of side-effects, and the degree to which the condition is over- or undertreated in the population. ${ }^{2,16}$ The public health impact of the ads on diverse individuals also depends on intricately interrelated characteristics of the DTC advertisement. These include the scientific evidence base for rational claims; the degree, type, target, and focus of the ad's emotional appeals; and the balance of risk/benefit information and rational/emotional appeals for different target groups and those likely to be caught in the crossfire of the broad audiences reached by DTC marketing. ${ }^{2}$ This complexity makes any attempt at regulation easier said than done. ${ }^{10}$

DTC ads distort the relationship between patients and clinicians. ${ }^{13,17,18}$ DTC ads manipulate the patient's agenda and steal precious time away from an evidencebased primary care clinician agenda that is attempting to promote healthy behavior, screen for early-stage treatable disease, and address mental health. The negative consequences of this manipulation of the public, the patient, the clinician, and their relationship are subtle but pervasive. An insidious adverse effect occurs in what is not done during the limited time of a visit. Discussing why the advertised drug is not the best option for a particular patient may mean that a mammogram is not ordered, an important health behavior is not discussed, a family matter is not brought up, a deeper patient concern is never articulated, a diagnosis for which there is no drug ad is not made. The clinician is put in the role of gatekeeper for the advertised commodity rather than a gateway for prioritizing health care based on the concerns of patients and the science-based recommendations for preventive, chronic disease, mental health, and family care.

Another important and hard-to-measure effect of DTC ads is their influence on people's perceptions of 
health and how it should be maintained or regainedthe realm of public health. Frosch and colleagues found that DTC ads promote drugs over healthy lifestyle. ${ }^{1}$ Furthermore, there is reasonable concern that DTC ads may promote a perception of vulnerability and illness for which the advertised drug is the solution ${ }^{19}$ and encourage viewers to consider medical causes for their everyday experiences. ${ }^{20}$ The goal of public health is to promote the health of the population, not to incite fear or anxiety about the symptoms of life. Arguments that ads designed to sell drugs promote the public health ring hollow.

Activating patients to be more knowledgeable about their health and health care and to communicate better with their physician are worthy goals. There is a need for greater accessibility to unbiased information for the public and the profession. ${ }^{21}$ However, DTC ads manipulate rather than give power to patients because they are fundamentally designed to sell drugs, not to provide the balanced information that truly empowers.

In an article in USA Today, ${ }^{22}$ Ken Johnson, senior vice president of the Pharmaceutical Research and Manufacturers of America (PhRMA), was quoted as saying about the Frosch research: "The study does not reflect any of the positive changes in DTC advertisements over the past 12 months," namely, the "PhRMA Guiding Principles: Direct-to-Consumer Advertisements About Prescription Medicines." ${ }^{23}$ This guideline states that "DTC communications about prescription medicines serve the public health." It is not clear, however, that these voluntary guidelines are preventing the manipulation identified in the Frosch et al study. If anything, it appears to me that drug advertisers are emboldened to manipulate further the clinician-patient relationship and the public's perception of the need for drugs.

I encourage readers to print out the PhRMA "Guiding Principles,"23 available online at http://www.phrma.org/ files/DTCGuidingprinciples.pdf, and have them in front of you the next time you see a DTC ad. This experiment is useful to assess the degree to which the guidelines are guiding DTC advertising practice. It also may point out the challenges of enacting these principles.

For example, in a recent multimedia ad campaign, a drug with potentially life-threatening side effects is put forth as the solution for abdominal feelings that are common for most people, but which may signify an annoying and occasionally severely debilitating condition for a small number of people, or which may indicate a number of other conditions. ${ }^{24}$ Viewers are encouraged to tell their doctor about their symptoms and to expect their doctor to suggest fiber and laxatives. (Diet changes, physical activity, and other nonmagic-bullet solutions are not mentioned.) The subtle implication is that by suggesting fiber or laxatives, the doctor is not taking the patient seriously. The ad goes on to suggest that if the patient persists, the doctor will prescribe this drug. The drug, with its serious side effect profile, should be considered only for a very narrow range of patients. But it is the public that is being encouraged to amplify their symptoms and to discount a dietary change (increasing fiber), which would be beneficial for many, in favor of a drug that is inappropriate for a majority of viewers with symptoms. Disparaging fiber and doctors' personalized advice to possibly benefit a few has the potential to harm many.

The PhRMA "Guiding Principles" say that DTC ads "should foster responsible communications between patients and health care professionals to help patients achieve better health." ${ }^{23}$ How are communication and health fostered by manipulating patient-clinician communication toward drugs and away from health behavior, or by denigrating clinician recommendations for nonpharmacological health interventions? How does a broad-based medium designed to sell to the masses promote drugs in the individualized way that is essential for safety if the message largely reaches people who are not candidates for the drug? How does it improve public health to bombard the public with the message that life is happier, more fulfilling, more socially acceptable on drugs? What are the unintended consequences of the plethora of images and messages about health that are intended to increase patient demand for drugs?

One unintended consequence is likely to be worsening of inequalities in health care and health. Research has shown reduced comprehension of DTC ads for viewers with limited literacy ${ }^{25}$ and lower health knowledge, ${ }^{26}$ raising concerns about the effect of ads in increasing disparities. ${ }^{27}$ Further research is needed to examine how the complex mix of rational and emotional appeals affect different groups. Without such research, DTC ads must be considered a huge, uncontrolled public health experiment on the American people.

The United States and New Zealand should join the rest of the industrialized world in acting on the realization that for the good of the public, DTC ads should be banned. ${ }^{28,29}$

Accomplishing a ban will require self-examination by the public, health care professions, PhRMA, and the health care policy community.

The public needs to examine the degree to which it is manipulated to seek magic-bullet pills for health problems. We must be aware of the extent to which the shotgun approach of DTC advertising catches many of us in the crossfire of biased informational and emotional appeals that create free-floating anxiety and a sense of un-wellness for the many to sell drugs to the few who can benefit. Overt and covert appeals to seek 
drugs should not be confused with legitimate desires to improve knowledge of health and illness, reduce symptoms, improve health, empower communication with health care professionals, and gain social approval or a sense of control of life. Ads designed to sell drugs are not our unbiased allies in improving health care or health. Less-biased sources of information are available and need further development. Individuals, family members, communities, and health care professionals who know us as individuals are more qualified than DTC ads to help us to decide how to achieve our life goals and social roles.

As health care professionals, we need to examine the degree to which our acceptance of gifts and biased information from pharmaceutical companies ${ }^{30,31}$ and our willingness to use direct-to-consumer appeals to sell our own services diminishes our moral authority to act for the public good. ${ }^{29,32-34}$ In a recently published book, ${ }^{30}$ Brody concludes that we are at a tipping point in the relationship between the health care profession and drug manufacturers. In part because of this, the pharmaceutical industry is pushing public demand. Recognizing that knowledge is power, we need to be willing to share that power with patients and to support their access to unbiased sources of information about health and health care. We need to clean our own house if we want to be positioned to be strong advocates for what is right for the health of patients and the public.

The pharmaceutical industry has a vital role in assuring the public health through drug discovery, manufacture, and distribution. They have lost their way in the aggressive pursuit of direct-to-consumer advertising. The pharmaceutical industry deserves the support of the public, policy makers, and the health care professions in refocusing on its crucial roles in developing and bringing drugs to market.

For policy makers, legislators, and government administrators, the challenge is to keep a larger perspective, resist intrusions of power and money involved in selling more drugs, and to keep focused on the greater public good.

All of these communities need to support the public's desire for legitimate health information. More needs to be done to make available unbiased information to support personalized decision making and action. ${ }^{14,21}$ PhRMA has a legitimate role in helping to make this information available within guidelines that already have been proposed. ${ }^{35}$ Advertisements designed to sell drugs are not the answer to the need for balanced health and health care information.

In addition to self-reflection, action is needed if the insidious, pervasive, detrimental, and misconstrued effects of DTC ads are to be stemmed in the United States and New Zealand, as they have been in the rest of the developed world. By calling for self-reflection before action, I am suggesting that we all tie into our deepest motivations, where we may find immense common ground among all stakeholders. Many joined the pharmaceutical industry based on a deep desire to help people. Similar motivations underlie many in the health and policy professions. The day-to-day press for resources and Americans' nearly unmitigated desire for "more" can make us forget to slow down, listen, and find a course of collective action based on those deep values we share.

This does not mean that I think that meaningful industry self-regulation or even outside regulation of DTC ads is possible. Only a ban will work. The impossibility of regulating complex overt and covert multichannel messages with both rational and emotional appeals, the power imbalance between the public good and the commercial imperative, the difficulty of anticipating ads' unintended consequences, and the availability of less-biased sources of information and motivation all argue for totally proscribing DTC ads. Such a ban can help us to refocus on our genuine roles: PhRMA developing, producing, and distributing drugs; health care professionals and patients pursuing health together with minimal commercial manipulation; and policy makers pursing the public good.

To read or post commentaries in response to this article, see it online at http://www.annfammed.org/cgi/current/full/5/2/101.

Submitted March 7, 2007; accepted March 7, 2007.

Key words: Advertising/direct-to-consumer; drug industry; doctorpatient relationship; public health

Disclaimer: The opinions expressed are those of the author and do not necessarily represent the views of the sponsoring organizations of the Annals.

\section{References}

1. Frosch DL, Krueger PM, Hornik RC, Cronholm PF, Barg FK. Creating demand for prescription drugs: a content analysis of television direct-to-consumer-advertising. Ann Fam Med. 2007;5(1):6-13.

2. Stange KC. On TRACK: Intended and unintended consequences of direct-to-consumer drug marketing. Ann Fam Med. 2007;5(2):175-179.

3. Kessler DA, Levy DA. Direct-to-consumer advertising: is it too late to manage the risks? Ann Fam Med. 2007;5(1):4-5.

4. Glinert LH. TV commercials for prescription drugs: a discourse analytic perspective. Res Social Adm Pharm. 2005;1(2):158-184.

5. Sumpradit N, Ascione FJ, Bagozzi RP. A cross-media content analysis of motivational themes in direct-to-consumer prescription drug advertising. Clin Ther. 2004;26(1):135-154.

6. Kaphingst KA, Dejong W, Rudd RE, Daltroy LH. A content analysis of direct-to-consumer television prescription drug advertisements. J Health Commun. 2004;9(6):515-528.

7. Almasi EA, Stafford RS, Kravitz RL, Mansfield PR What are the public health effects of direct-to-consumer drug advertising? PLoS Med. 2006;3(3):e145. Epub 2006 Mar 28. 
8. Klausner JD, Kim A, Kent C. Are HIV drug advertisements contributing to increases in risk behavior among men in San Francisco, 2001? AIDS. 2002;16(17):2349-2350.

9. Hansen RA, Shaheen NJ, Schommer JC. Factors influencing the shift of patients from one proton pump inhibitor to another: the effect of direct-to-consumer advertising. Clin Ther. 2005;27(9):1478-1487.

10. Gilbody S, Wilson P, Watt I. Benefits and harms of direct to consumer advertising: a systematic review. Qual Saf Health Care 2005;14(4):246-250.

11. Kravitz RL, Epstein RM, Feldman MD, Franz CE, Azari R, Wilkes MS, Hinton L, Franks P. Influence of patients' requests for direct-toconsumer advertised antidepressants: a randomized controlled trial. JAMA. 2005;293(16):1995-2002.

12. Donohue JM, Berndt ER, Rosenthal M, Epstein AM, Frank RG. Effects of pharmaceutical promotion on adherence to the treatment guidelines for depression. Med Care. 2004;42(12):1176-1185.

13. Murray E, Lo B, Pollack L, Donelan K, Lee K. Direct-to-consumer advertising: public perceptions of its effects on health behaviors, health care, and the doctor-patient relationship. J Am Board Fam Pract. 2004;17(1):6-18.

14. Morgan S, Mintzes, B, Barer M. The economics of direct-to-consumer advertising of prescription-only drugs: prescribed to improve consumer welfare? J Health Serv Res Policy. 2003;8:237-244.

15. Bradford WD, Kleit AN, Nietert PJ, Steyer T, Mcllwain T, Ornstein S. How direct-to-consumer television advertising for osteoarthritis drugs affects physicians' prescribing behavior. Health Aff (Millwood). 2006;25(5):1371-1377.

16. Kravitz RL. Towards a framework for improving DTCA [eletter]. http:// www.annfammed.org/cgi/eletters/5/1/6\#5211, 4 February 2007.

17. Mintzes B, Barer ML, Kravitz RL, et al. How does direct-toconsumer advertising (DTCA) affect prescribing? A survey in primary care environments with and without legal DTCA. CMAJ. 2003;169(5):405-412.

18. Robinson AR, Hohmann KB, Rifkin Jl, et al. Direct-to-consumer pharmaceutical advertising: physician and public opinion and potential effects on the physician-patient relationship. Arch Intern Med. 2004;164(4):427-432.

19. Lacasse JR, Leo J. Serotonin and depression: A disconnect between the advertisements and the scientific literature. PLoS Med. 2005;2: e392 DOI: 10.1371/journal.pmed.0020392.

20. Woloshin S, Schwartz LM, Tremmel J, Welch HG. Direct-to-consumer advertisements for prescription drugs: what are Americans being sold? Lancet. 2001;358(9288)1141-1146.
21. Deyo RA, Patrick DL. Hope or Hype: The Obsession With Medical Advances and the High Cost of False Promises. New York, NY: New York American Management Association; 2005.

22. Rubin R. Analysis: Prescription drug ads leave out risks, alternatives. USA Today. Available at: http://www.usatoday.com/news/health/200701-29-prescription-drug-ad_x.htm. Accessed: 2 March 2007.

23. PhRMA. Guiding Principles: Direct-to-Consumer Advertisements About Prescription Medicines. Available at: http://www.phrma.org/ files/DTCGuidingprinciples.pdf. Accessed 2 March 2007.

24. Novartis Pharmaceuticals Corporation. Your search for relief may be over [advertisement]. Available at: http://www.zelnorm.com/index. jsp? source $=01030$ Ecampaign $=$ ZEL-9648\& site $=100005$ \&placement $=100196 \varepsilon$ creative $=100002$. Accessed: 3 March 2007.

25. Kaphingst KA, Rudd RE, DeJong W, Daltroy LH. Comprehension of information in three direct-to-consumer television prescription drug advertisements among adults with limited literacy. J Health Commun. 2005;10(7):609-619.

26. Hoek J, Maubach N. Consumers' knowledge, perceptions, and responsiveness to direct-to-consumer advertising of prescription medicines. N Z Med J. 2007;120(1249):U2425.

27. Welch Cline RJ, Young HN. Marketing drugs, marketing health care relationships: a content analysis of visual cues in direct-to-consumer prescription drug advertising. Health Commun. 2004;16(2):131-157.

28. Mintzes B. Television advertisements for medicines and the myth of the magic pill [eletter]. http://www.annfammed.org/cgi/eletters/5/1/6\#5135, 30 January 2007.

29. Scott JG. Selling soap [eletter]. http://www.annfammed.org/cgi/eletters/5/1/6\#5176, 1 February 2007.

30. Brody H. Hooked: Ethics, the Medical Profession, and the Pharmaceutical Industry. Lanham, MD: Rowman and Littlefield; 2007.

31. Abramson J. Overdosed America: The Broken Promise of American Medicine. New York, NY: HarperCollins; 2004:156-157.

32. Allen RE. End direct-to-DOCTOR advertising, not DTCA [eletter]. http://www.annfammed.org/cgi/eletters/5/1/6\#5239 8 February 2007.

33. Brody $\mathrm{H}$. What part of "selling" don't you understand [eletter]? http:// www.annfammed.org/cgi/eletters/5/1/6\#5158, 1 February 2007.

34. Brody H. Reply to AE [eletter]. http://www.annfammed.org/cgi/eletters/3/1/82\#5093, 21 January 2007.

35. Woloshin S, Schwartz LM, Welch HG. The value of benefit data in direct-to-consumer drug ads. Health Aff (Millwood). 2004;(Suppl Web Exclusives)W4-234-245. 